\title{
Okul Müdürlerinin İş Doyumu: Nitel Bir Çalışma a
}

\author{
Suzan CANLI ${ }^{\mathrm{b}}$, , Şevket SINNDİ
}

\section{Özet}

$\mathrm{Bu}$ araştırmada okul müdürlerinin iş doyumlarını iş ve çalışma ortamı açısından incelemek amaçlanmıştır. Araştırmada nitel araştırma desenlerinden olgubilim deseni kullanılmıştır. Çalışma grubu maksimum çeşitlilik örnekleme yöntemiyle belirlenen 18 okul müdüründen oluşmaktadır. Veri toplama aracı olarak yarı yapılandırılmış görüşme formu kullanılmıştır. Araştırma sonucuna göre okul müdürlerinin çoğunluğu ödül, müdürlük görevinin toplumsal statüsü, ücret, kendini geliştirme ve yükselme açısından iş doyumsuzluğu yaşamaktadır. Araştırmadan elde edilen bir diğer sonuç okul müdürlerinin görevin niteliklerine, astlarına ve çalışma koşullarına ilişkin hoşnutluklarının ve hoşnutsuzluklarının bulunmasıdır. Araştırma sonucuna göre okul müdürlerinin iş doyumunu artıracak önerilerde bulunulmuştur. Ayrıca alanyazına katkı sağlayacak çalışmalar konusunda araştırmacılara önerilerde bulunulmuştur.
Anahtar Kelimeler

İş Doyumu

Okul Müdürü

Okul

Nitel Çalışma

Makale Hakkında

Geliş Tarihi: 24.10.2019

Kabul Tarihi: 10.05.2021

Doi: 10.18026/cbayarsos.637436

\section{Job Satisfaction of School Principals: A Qualitative Study}

\begin{abstract}
It was aimed to examine job satisfaction of school principals in terms of work and work environment in this research. Phenomenology design, one of the qualitative research designs, was used in the research. The study group consisted of 18 school principals determined by maximum diversity sampling method. A semi-structured interview form was used as data collection tool. According to the results of this research, the majority of school principals experience job dissatisfaction in terms of reward, social status of the principal profession, wage, self-development and promotion. Another result obtained from this research is that the school principals have satisfaction and dissatisfaction with the qualifications of the job, subordinates and working conditions of the school. According to the results of this research, suggestions were made to increase job satisfaction of school principals. In addition, suggestions were made to the researchers about the studies that would contribute to the literature.
\end{abstract}

Keywords

Job Satisfaction

School Principal

School

Qualitative Study

About Article

Received: 24.10.2019

Accepted: 10.05 .2021

Doi: 10.18026/cbayarsos.637436

aBu makale 3-5 Mayıs 2018 tarihinde Alanya'da gerçekleştirilen 4. Uluslararası Eğitim Bilimleri Sempozyumu'nda sözlü olarak sunulan bildirinin gözden geçirilmiş halidir. 


\section{Giriş}

Birden fazla kişinin ortak bir amacı gerçekleştirmek amacıyla oluşturduğu yapı olan örgütlerde verimlilik önemli faktörlerden biridir. Bu sebepledir ki örgütsel araştırmaların temel odağ 1 verimliliği artırmak olmuştur. Örgütlerde yapılan ilk araştırmalarda verimliliği artırmak için örgütsel yapının önemi vurgulanmış ve örgütlerin sosyal yönü ihmal edilmiştir. Ancak Hawthorne araştırmalarıyla örgütsel verimliliği artırmada insan faktörünün önemi anlaşılmış ve örgütün sosyal yönlerine dikkat çekilmiştir. Böylelikle örgütün sosyal yönlerine ağırlık verilmeye başlanmış, yönetimde çalışanların psikolojik ve sosyal ihtiyaçlarını anlamak ve bunları karşılamak önemsenmiş (Şişman, 2016) olup bu konuda pek çok araştırma yapılmıştır. Bu araştırmaların yoğunlaştığı konulardan biri de iş doyumudur.

İş doyumu, çalışanın işini veya iş yaşamını değerlendirmesi sonucunda haz duyması ve pozitif bir duygusal duruma ulaşmasıdır (Lawler, 1976, akt. Başaran, 2008). İş doyumu, çalışanların işine yönelik tutumudur. Bu tutumların olumlu olması iş doyumunun yüksek, olumsuz olması ise iş doyumunun düşük olduğunu göstermektedir (Özkalp ve Kırel, 2018). Bu açıdan iş doyumunun çalışanların işlerine karşı geliştirmiş oldukları tutumlardan oluştuğu ve iş yaşantısına yönelik duygusal tepkiler olduğu belirtilmektedir (Avşaroğlu, Deniz ve Kahraman, 2005). İş doyumunun önemsenmesinin belki de en önemli nedeni "Mutlu-üretken işçi hipotezi" (Wright ve Cropanzano, 2000, s. 84), yani memnun bir çalışanın mutlu bir çalışan olduğu, mutlu bir çalışanın da başarılı bir çalışan olduğudur (Aziri, 2011). Şöyle ki iş doyumu insana gösterilen iyi bir muamelenin yansıması olup insanın duygusal ve psikolojik sağlı̆̆ının bir göstergesi olarak kabul görmektedir. Ayrıca iş doyumunun çalışanların örgütsel işlevselliği etkileyen davranışlarına neden olduğu belirtilmekte olup iş doyumun sağlanmasıyla çalışanların olumlu davranışlar, iş doyumunun sağlanmadığ çalışanların olumsuz davranışlar gösterebileceği belirtilmektedir. Böylelikle iş doyumunun örgütsel işlevselliğin bir göstergesi olabileceği vurgulanmaktadır (Spector, 1997). Bu açıdan iş doyumunun hem bireysel hem de örgütsel açıdan önemli olduğu söylenebilir. Nitekim iş doyumunun çalışanların fiziksel, zihinsel ve psikolojik sağlıklarıyla ilişkili olduğu belirlenmiş olmakla birlikte iş doyumu ile tükenmişlik, özsaygı, depresyon ve kaygı arasında oldukça güçlü ilişkilerin bulunduğu da tespit edilmiştir (Faragher, Cass ve Cooper, 2005). Ayrıca iş doyumu arttıkça yaşam doyumu (Avşaroğlu ve diğerleri, 2005; Dikmen, 1995; Fırat ve Cula, 2016; Judge ve Watanabe, 1993; Kırcı-Çevik ve Korkmaz, 2014; Kubilay, 2013) örgütsel vatandaşllık (Yllmaz, 2012), performans (Judge, Thoresen, Bono ve Patton, 2001; Koç, Yazıcıoğlu ve Hatipoğlu, 2009), örgütsel yaratıcllık (Yılmaz ve Izgar, 2009) ve örgütsel özdeşleşme (Çırakoğlu, 2010) artmakta; yabancılaşma (Turan ve Parsak, 2011) ve işten ayrılma niyeti (Çekmecelioğlu, 2006) azalmaktadır.

İş doyumunun hem bireysel hem de örgütsel sonuçları farklı alanlarda ilgi duyulan bir konu olmasına neden olmuştur. Ülkemizdeki eğitim araştırmalarında hem öğretmenlerin hem de okul yöneticilerinin iş doyumuna ilişkin çalışmalar bulunmakla birlikte okul müdürlerinin iş doyumuna ilişkin araştırmalar sınırlı sayıdadır. Ancak okul müdürü "okulun amaçlarını gerçekleştirmek üzere tüm kaynakların etkili ve verimli kullanımından, ekip ruhu anlayışıyla yönetiminden ve temsilinden birinci derecede sorumlu eğitim ve öğretim lideri" olarak belirtilmektedir (Milli Eğitim Bakanlığı [MEB], 2013). Bu durumda okulun etkililiğinden birinci derecede sorumlu olan okul müdürüdür. İş doyumunun okul etkililiğini etkilemekte olduğu (Yıldırım, Akan ve Yalçın, 2017) kanıtına dayanılarak iş doyumu yaşamayan bir okul müdürünün okul etkililiğine yeterli katkıyı sunamayacağı söylenebilir. Diğer yandan iş 
doyumunu etkileyen faktörlerden biri yönetimin niteliği olduğuna (Başaran, 2008) göre okul müdürlerinin tutumlarının ve davranışlarının öğretmenlerin iş doyumunu etkileyebileceği söylenebilir. Yapılan araştırmalarda okul müdürlerinin liderlik stillerinin (Aydın, Sarıer ve Uysal, 2013) ve mizah yeteneklerinin (Recepoğlu, 2008) öğretmenlerin iş doyumunu etkilediği sonucuna ulaşılmıştır. Bu bağlamda iş doyumu yaşamayan bir okul müdürünün sergileyebileceği olumsuz davranışlar öğretmenlerin de iş doyumunu azaltabilir.

Ülkemizde okul müdürlerinin iş doyumuna ilişkin çalışmalar nicel olarak gerçekleştirilmiştir. Okul müdürlerinin iş doyumlarının nitel olarak incelendiği araştırmalara rastlanılmamıştır. Yapılan nicel araştırmalarda kullanılan ölçme araçlarına dayalı olarak belirli boyutlar ve maddeler açısından okul müdürlerinin iş doyumu belirlenmektedir. Oysa okul müdürlerinin görevlerinde ve rollerinde meydana gelen değişimler (Balyer, 2012) sonucunda iş doyumlarında değişiklik oluşabilir. Yapılacak nitel araştırmalarla okul müdürlerinin iş doyumuna ilişkin ayrıntılı ve kapsamlı bilgiler edinilebilir. Bu açıdan araştırmada okul müdürlerinin iş doyumu nitel araştırma yöntemiyle incelenmiştir. Okul müdürlerinin iş doyumlarının hangi açılardan ele alınacağını belirlemek için iş doyumunu etkileyen faktörler incelenmiştir. Crossman ve Harris'e (2006) göre iş doyumunu etkileyen faktörler çevresel faktörler, psikolojik faktörler veya demografik faktörler olarak sınıflandırılabilir. $\mathrm{Bu}$ araştırmada çevresel faktörler olarak ele alınan iş ve çalışma ortamı açısından okul müdürlerinin iş doyumuna açıklık getirilmeye çalışılmıştır. Araştırmada okul müdürlerinin iş doyumu işin niteliği, ücret, işin toplumsal statüsü, ödül, gelişme ve yükselme olanakları, astlar ve çalışma koşulları açısından incelenmiştir. Bununla birlikte alanyazında iş doyumunun çalışan memnuniyeti olarak da ele alındığı görülmektedir. Ancak bu iki kavram birbirinden farklıdır. Çalışan memnuniyeti daha geniş bir kavram olup iş doyumunu da kapsamaktadır. İş doyumu bireyin işinden aldığı doyumu ifade ederken, çalışan memnuniyeti örgüt ile olan duygusal ve maddi bağlara ve ilişkilere yönelik tutumları da içermektedir (Soylu, 2004). Doyum ve memnuniyet kavramlarının anlamı da birbirinden farklıdır (Şahin, Çek ve Zeytin, 2011). İş doyumunun bireylerin işlerinden hoşlanma veya hoşlanmama derecesini belirtmesi (Spector, 1997) nedeniyle araştırmada hoşnutluk ve hoşnutsuzluk kavramları tercih edilmiştir.

\section{Araştırmanın Amacı}

$\mathrm{Bu}$ araştırmada okul müdürlerinin iş doyumlarını iş ve çalışma ortamı açısından incelemek amaçlanmıştır. Bu amaçla "Okul müdürlerinin müdürlük görevinin nitelikleri, görevleri karşılığında aldıkları ücret, görevlerinin toplumsal statüsü, görevlerindeki performansları karşılığında aldıkları ödüller, görevlerinde kendilerini geliştirme ve yükselme olanakları, astları ve görev yaptıkları okulun çalışma koşulları açısından iş doyumları nasıldır?" sorusuna yanit aranmiştır.

\section{Yöntem}

Araştırmada nitel araştırma desenlerinden olgubilim deseni kullanılmıştır. Olgubilim araştırmaları bilinen bir olguya ilişkin ayrıntılı bir bakış açısı sunmak amacıyla yapılır (Yıldırım ve Şimşek, 2011). Bu araştırmada da okul müdürlerinin iş doyumları iş ve çalışma ortamı açısından ayrıntılı bir şekilde incelenmiştir. 


\section{Çalışma Grubu}

Araştırmada farklı kademelerde görev yapan okul müdürlerinin iş doyumlarına ilişkin ortak ve farklı yönlerin ortaya konularak problemin daha geniş bir şekilde betimlenmesi için çalışma grubu maksimum çeşitlilik örnekleme yöntemi kullanılarak belirlenmiştir (Büyüköztürk, Kılıç-Çakmak, Akgün, Karadeniz ve Demirel, 2016). Araştırmanın çalışma grubu 2017-2018 eğitim öğretim yılında Adıyaman Merkez ilçe sınırları içerisinde bulunan farklı kademelerdeki okullarda görev yapan 18 okul müdüründen oluşmaktadır. Çalışma grubuna ilişkin demografik bilgiler Tablo 1'de gösterilmiştir.

Tablo 1. Çalışma Grubuna İlişkin Demografik Bilgiler

\begin{tabular}{|c|c|c|c|c|c|}
\hline No & Cinsiyet & Branş & Yaş & $\begin{array}{l}\text { Yöneticilik } \\
\text { Kıdemi }\end{array}$ & Okul Türü \\
\hline M1 & Erkek & Görsel Sanatlar & 48 & 17 & Ortaokul \\
\hline M2 & Erkek & Din Kültürü ve Ahlak Bilgisi & 46 & 8 & Ortaokul \\
\hline M3 & Erkek & Türkçe & 53 & 8 & Ortaokul \\
\hline M4 & Erkek & Tarih & 45 & 12 & Lise \\
\hline M5 & Erkek & Türkçe & 40 & 13 & Ortaokul \\
\hline M6 & Erkek & Tarih & 45 & 7 & Lise \\
\hline M7 & Erkek & Din Kültürü ve Ahlak Bilgisi & 47 & 4 & Ortaokul \\
\hline M8 & Erkek & Makine Teknolojisi & 44 & 14 & Lise \\
\hline M9 & Erkek & Sınıf Öğretmeni & 45 & 21 & İlkokul \\
\hline M10 & Erkek & Sınıf Öğretmeni & 48 & 3 & İlkokul \\
\hline M11 & Erkek & Fen Bilimleri & 50 & 15 & Ortaokul \\
\hline M12 & Erkek & İHL Meslek Dersleri & 52 & 3 & Lise \\
\hline M13 & Erkek & Sosyal Bilgiler & 42 & 10 & Ortaokul \\
\hline M14 & Erkek & İlköğretim Matematik & 42 & 8 & Ortaokul \\
\hline M15 & Erkek & Sınıf Öğretmeni & 47 & 13 & İlkokul \\
\hline M16 & Erkek & Sınıf Öğretmeni & 54 & 14 & İlkokul \\
\hline M17 & Kadın & Okulöncesi Öğretmenliği & 46 & 3 & Anaokulu \\
\hline M18 & Kadın & Okulöncesi Öğretmenliği & 38 & 11 & Anaokulu \\
\hline
\end{tabular}

\section{Veri Toplama Aracı}

Araştırmada veri toplama aracı olarak yarı yapılandırılmış görüşme formu kullanılmıştır. Görüşme formu hazırlanmadan önce iş doyumuna ilişkin alanyazın taraması yapılarak 7 soruluk bir görüşme formu hazırlanmıştır. Hazırlanan taslak görüşme formunun okul müdürlerinin iş doyumuna ilişkin görüşlerini belirlemeye uygun olup olmadığını incelemesi için Eğitim Yönetimi alanında çalışan bir öğretim üyesine gönderilmiştir. Alınan dönüt ile 
görüşme formundaki bir soruda ifade değişikliği yapılmış, üç soru ise ikili sorular olacak şekilde ayırılarak 10 soruluk (Görüşme formundaki sorulardan bazıları: Müdürlük görevinin hangi nitelikleri bu görevi yürütmekten hoşnut olmanızı sağlamaktadır? Görev yaptığınız okulun çalışma koşullarına ilişkin hoşnutluklarınız nelerdir?) bir görüşme formu hazırlanmıştır. Hazırlanan bu görüşme formu 3 okul müdürüne verilerek soruların açık ve anlaşılır olup olmadı̆̆ına ilişkin görüşleri istenmiştir. Alınan dönütler sonucu görüşme formunun açık ve anlaşılır olduğu belirlenmiştir.

Görüşme formu iki bölümden oluşmaktadır. Birinci bölümde katılımcılara ilişkin kişisel bilgilere (cinsiyet, branş, yaş, yöneticilik kıdemi ve görev yapılan okul türü) yer verilmiştir. İkinci bölümde katılımcıların iş doyumunu belirlemeye yönelik 10 soru bulunmaktadır.

\section{Verilerin Toplanması ve Analizi}

Araştırmanın verileri oluşturulan görüşme formu aracılı̆̆ıyla toplanmıştır. Elde edilen verilerin analizinde içerik analizi kullanılmıştır. Veriler analiz edilmeden önce her bir görüşme formu M1, M2, M3... şeklinde isimlendirilmiştir. Görüşme formundaki her bir soru ayrı ayrı incelenerek ifadelerin özüne bağlı kalınarak kodlamalar yapılmıştır. Oluşturulan bu kodlamalar ortak özellikleri bakımından gruplandırılarak temalar elde edilmiştir. Verilerin analizi iki araştırmacı tarafından ayrı ayrı yapılarak uyuşum yüzdesi yaklaşık \%93 olarak hesaplanmıştır. Her bir tema için frekanslar hesaplanmıştır.

\section{Araştırmanın Geçerliği ve Güvenirliği}

Araştırmanın geçerliğini ve güvenirliğini sağlamak için iş doyumuna ilişkin alanyazın taraması yapılmış, hazırlanan taslak görüşme formunun okul müdürlerinin iş doyumuna ilişkin görüşlerini belirlemeye uygun olup olmadığını incelemesi için Eğitim Yönetimi alanında çalışan bir öğretim üyesine gönderilmiştir. Alınan dönüt ile gerekli değişiklikler yapılmıştır. Görüşme formu 3 okul müdürüne verilerek soruların açık ve anlaşılır olup olmadığına ilişkin görüşleri istenmiştir. Alınan dönütler sonucu görüşme formunun açık ve anlaşılır olduğu belirlenmiştir. Elde edilen bulgular 3 okul müdürüyle paylaşılarak katılımcı teyidi alınmıştır. Bulguların sunumunda okul müdürlerinin bireysel olarak dile getirdiği ifadelerden örneklere yer verilmiştir. Verilerin analizi iki araştırmacı tarafından yapılarak uyuşum yüzdesi belirlenmiştir. Uyuşum sağlanamayan kodlarda görüşme formundaki ilgili yanıt tekrar okunarak her iki araştırmacı tarafından ortak bir görüşe varılmıştır. Katılımcı okul müdürleri ile ilgili demografik bilgiler ve araştırmanın tüm süreçlerine ilişkin bilgiler ayrıntılı olarak belirtilmiştir.

\section{Bulgular}

Araştırmada okul müdürlerinin iş doyumuna yönelik görüşlerinden elde edilen bulgular başlıklar halinde aşağıda açıklanmıştır.

\section{Görevin Nitelikleri}


Araştırmanın katılımcılarına "Müdürlük görevinin hangi nitelikleri bu görevi yürütmekten hoşnut olmanızı sağlamaktadır?" sorusu sorulmuş ve alınan cevaplar doğrultusunda okul müdürlerinin müdürlük görevinin niteliklerine ilişkin iş doyumunda elde edilen temalar ve frekanslar Şekil 1'de gösterilmiştir.

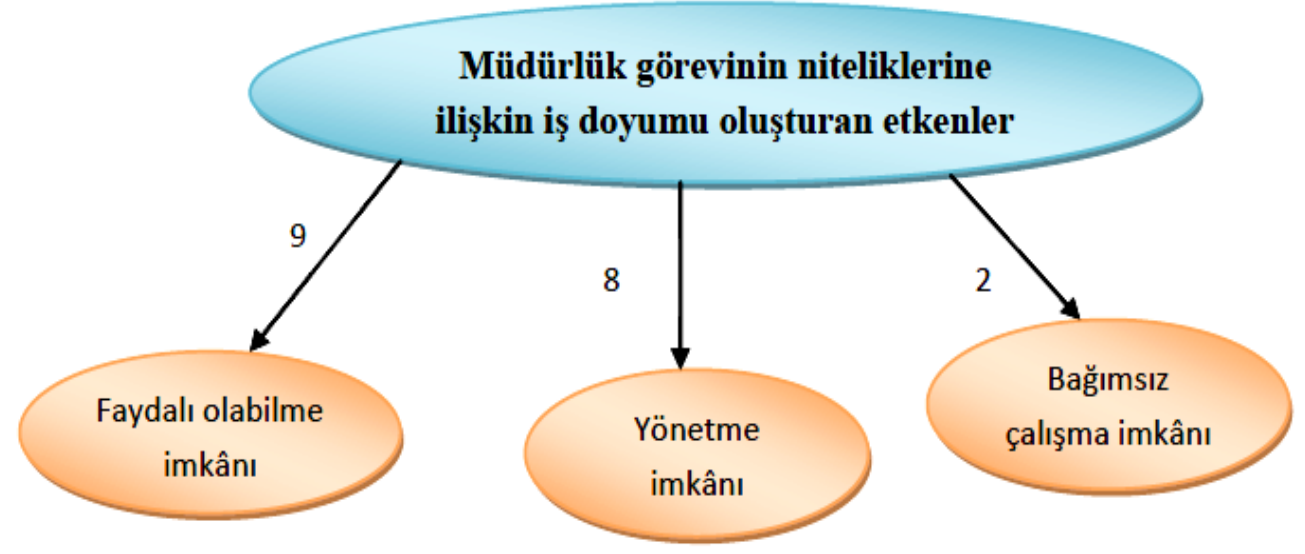

Şekil 1. Okul müdürlerinin müdürlük görevinin niteliklerine ilişkin iş doyumu oluşturan etkenler

Şekil 1'e göre okul müdürlerinin müdürlük görevinin niteliklerine ilişkin iş doyumu oluşturan etkenler "Faydalı olabilme imkânı, Yönetme imkânı ve Bağımsız çalışma imkânı" temaları altında toplanmıştır. "Faydalı olabilme imkânı" temasına göre okul müdürlerinin çoğunluğu üretebilme, nitelikli bir eğitim-öğretim hizmeti sunma, öğrencileri hedefine ulaştırmaya yardımcı olma, öğrencilere rol model olma, insanlara daha fazla faydalı olabilme, tecrübelerini meslektaşlarıyla paylaşma, daha fazla öğrenciye yardım edebilme, okulu geliştirme, öğrencilerin ve öğretmenlerin problemlerini çözme imkânı elde edebilmeleri nedeniyle müdürlük görevini yürütmekten hoşnutlardır. Okul müdürlerinden M2“Öğrencilerin en üst düzeyde eğitim-öğretim görmelerini să̆lamada vizyon ve misyon sahibi, bu işi dert edinmiş bir müdürün temel belirleyici olduğunu düşündüğüm için bu görevi yürütmeye çalışıyorum.", M13 ise "Öğretmen ve öğrencilerin sorunlarını çözmek, okulu fiziki ve akademik olarak sürekli daha iyi bir seviyeye getirmek için müdürlük yapıyorum." şeklinde faydalı olmanın verdiği hoşnutluğu ifade etmişlerdir.

"Yönetme imkânı" temasına göre bazı okul müdürleri müdürlük görevinde yönetme, planlama, organize etme, kararlarda etkili olma, yasa ve yönetmelikleri uygulama, çözümün merkezinde olma, doğru olanı gösterme ve liderlik yapma imkânı elde edebildiklerinden müdürlük görevini yürütmekten hoşnutturlar. Okul müdürlerinden M1 “... yöneten ve planlayan kişi olmak..." M17 ise "Bir yeri huzurlu ve mutlu bir şekilde yönetmek ve bir sistem oturtmak hoşuma gidiyor." şeklinde yönetmenin vermiş olduğu hoşnutluğu dile getirmişlerdir.

"Bağımsız çalışma imkânı" temasına göre bazı okul müdürleri kendi başlarına bir şeyler yapabilme ve istedikleri şeyleri gerçekleştirebilme imkânı elde edebildikleri için müdürlük görevini yürütmekten hoşnutturlar. Okul müdürlerinden M12 "Yapmak istediğim şeyleri gerçekleştirme imkânı bulma ve etkin olma bakımından bu görevi yürütüyorum." şeklinde bağımsız çalışma olanağından hoşnut olduğunu vurgulamıştır. 
Araştırmanın katılımcılarına "Müdürlük görevinin hangi nitelikleri bu görevi yürütmekten hoşnut olmamanıza neden olmaktadır?" sorusu sorulmuş ve alınan cevaplar doğrultusunda okul müdürlerinin müdürlük görevinin niteliklerine ilişkin iş doyumsuzluğunda elde edilen temalar ve frekanslar Şekil 2'de gösterilmiştir.

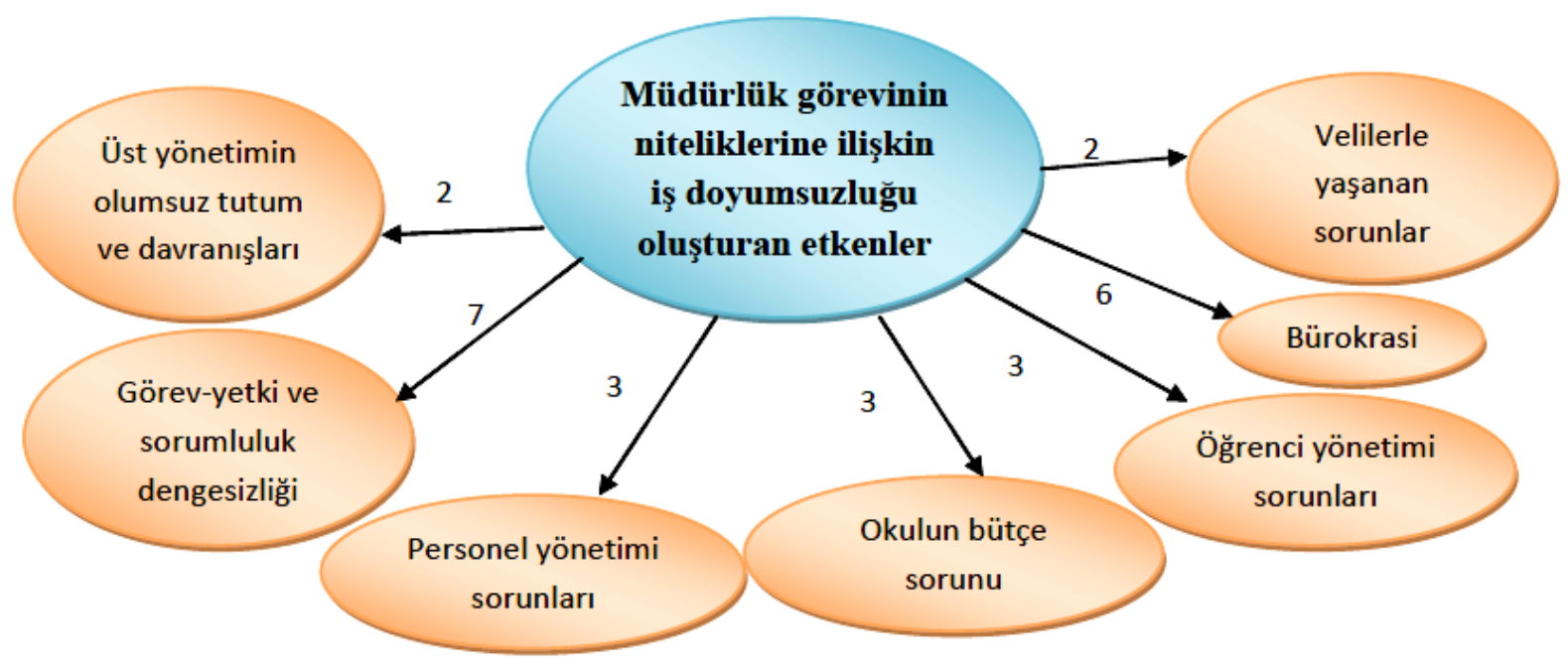

Şekil 2. Okul müdürlerinin müdürlük görevinin niteliklerine ilişkin iş doyumsuzluğu oluşturan etkenler

Şekil 2’ye göre okul müdürlerinin müdürlük görevinin niteliklerine ilişkin iş doyumsuzluğu oluşturan etkenler "Görev-yetki ve sorumluluk dengesizliği, Bürokrasi, Personel yönetimi sorunları, Okulun bütçe sorunu, Öğrenci yönetimi sorunları, Üst yönetimin olumsuz tutum ve davranışları, Velilerle yaşanan sorunlar" temaları altında toplanmıştır. "Görev-yetki ve sorumluluk dengesizliği" temasına göre okul müdürlerinin çoğunluğu görev alanlarının ve sorumluluklarının fazla yetkilerinin ise az olması nedeniyle müdürlük görevini yürütmekten hoşnut değillerdir. Okul müdürlerinden M11“Sorumluluk oranında yetki verilmemektedir. Yeteri kadar inisiyatif kullanamamaktayız.", M15 ise "...sorumluluk-yetki çatışması yaşamaktayız..." şeklinde görev ve sorumluluklarının fazla olmasına karşın yetkilerinin kısıtlı olmasından hoşnut olmadıklarını belirtmişlerdir.

"Bürokrasi" temasına göre bazı okul müdürleri bürokratik işlerle çok fazla ilgilenme, kuralları uygulamak zorunda olma, mevzuatın yeterince açık olmaması, eğitim sisteminin sürekli değişmesi, zamansız toplantılara katılma zorunluluğu, hızlı karar alıp uygulama zorunluluğu nedeniyle müdürlük görevini yürütmekten hoşnut değillerdir. Okul müdürlerinden M2 "Fazlaca bürokratik işlerle meşgul ediliyoruz. Çok fazla kuralcı olanlar rağbet görüyor. Halbuki inisiyatif alıp içtihat ederek işlerin hızl yürümesi ve daha içerikli olmasını să̆lamak daha önemlidir.", M8 “... mevzuat karmaşası... eğitim sisteminin yap-boz haline gelmesi...", M10 ise "Zamansız olarak yapılan toplantılara çă̆rılmak..."şeklinde bürokrasiye ilişkin bazı hoşnutsuzluklarını belirtmişlerdir.

"Personel yönetimi sorunları" temasına göre bazı okul müdürleri personeli çalıştırma zorluğu, personel arasındaki olumsuz ilişkiler, personelin çıkardığı sorunlar ve personel eksikliği ile ilgilenmek durumunda kaldıklarından müdürlük görevini yürütmekten hoşnut değillerdir. Okul müdürlerinden M1 "Üretmekten ve iş yapmaktan hoşlanmayanlara iş yaptırmak zorundayız...", M13 ise "... personelin sorun çözmeye değil sorun çıkarmaya meyilli olması hoşnut 
olmadığım faktörlerdir." şeklinde personel sorunlarına ilişkin hoşnutsuzluklarını dile getirmişlerdir.

“Öğrenci yönetimi sorunları” temasına göre bazı okul müdürleri öğrencilerin alan seçimindeki tutarsılılıları, olumsuz tutum ve davranışları ile ilgilenmek zorunda olma ve öğrencilerin güvenliğinden sorumlu olma nedeniyle müdürlük görevini yürütmekten hoşnut değillerdir. Okul müdürlerinden M4 "...ekonomik nedenlerden dolayı öğrencilerin alan-bölüm seçimindeki tutarsızlı̆̆ı..." M6 “...̈̈̆rencilerin lakayt-vurdumduymaz ve sorumsuz alışkanlıkları..." şeklinde öğrenci sorunlarıyla ilgili hoşnutsuzluklarını vurgulamışlardır.

"Okulun bütçe sorunu" temasina göre bazı okul müdürleri okulun geliri ile giderinin dengesizliği, ekonomik özerkliğin olmaması ve okulun bütçesiyle ilgilenmek zorunda olma nedeniyle müdürlük görevini yürütmekten hoşnut değillerdir. Okul müdürlerinden M13 "Okulun ihtiyaçlarının çok, gelirinin ve imkânlarının az olması..." şeklinde okulun bütçe sorununa ilişkin hoşnutsuzluğunu belirtmiştir.

"Üst yönetimin olumsuz tutum ve davranışları" temasına göre bazı okul müdürleri üst yöneticilerin baskısı, sahiplenme duygusunun olmaması ve okul müdürlerinin objektif olarak seçilmemesinden dolayı müdürlük görevini yürütmekten hoşnut değillerdir. Okul müdürlerinden M14 "...sübjektif kriterlerle okul müdürünün seçilmesinden hoşnut değilim.", M4 ise "...bazı üst yöneticilerin baskı yapması... çalışanı sahiplenme duygusunun olmaması... şeklinde üst yönetimin olumsuz tutum ve davranışlarından hoşnutsuzluklarını dile getirmişlerdir.

"Velilerle yaşanan sorunlar" temasına göre bazı okul müdürleri velilerin baskısı ve aşırı beklentileri ile karşı karşıya kaldıklarından müdürlük görevini yürütmekten hoşnut değillerdir. Okul müdürlerinden M8 “... velilerin olağanüstü beklentileri...” M4 ise “...velilerin sadece kendi çıkarlarını düşünerek baskı uygulaması..." şeklinde veli sorunlarından hoşnutsuzluklarını belirtmişlerdir.

\section{Ücret}

Araştırmanın katılımcılarına "Müdürlük göreviniz karşılığında aldığınız ücretin yeterliğine ilişkin düşünceleriniz nelerdir?" sorusu sorulmuş ve alınan cevaplar doğrultusunda okul müdürlerinin görevleri karşılığında aldıkları ücrete ilişkin iş doyumunda elde edilen temalar ve frekanslar Şekil 3'te gösterilmiştir.

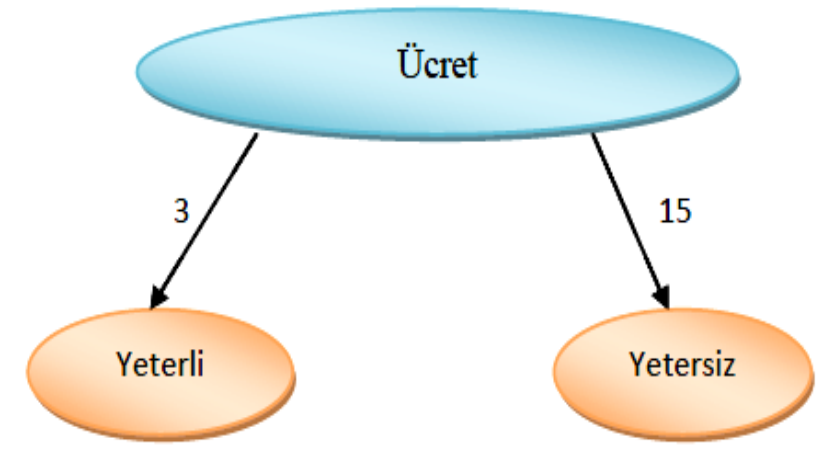

Şekil 3. Okul müdürlerinin görevleri karşılığında aldıkları ücrete ilişkin iş doyumuna yönelik görüşleri 
Şekil 3'e göre okul müdürlerinin çok az bir kısmı için görevleri karşılığında aldıkları ücret yeterli iken çoğunluğu için yetersizdir. Ücretin yetersiz olduğunu belirten okul müdürlerinden bazıları sorumluluklarının fazla ancak ücretlerinin az olduğunu, öğretmenlerle müdürler arasında maaş farklı olmadığını, öğretmenin ek derslerle müdürden daha fazla ücret aldığını, müdürlük için cazip bir ücret olması gerektiğini, okul türüne ve öğrenci sayısına göre ücretlerin farklılaştırılması gerektiğini belirtmişlerdir. Ücretin yetersizliğini belirten okul müdürlerinden M1“Öncelikle öğretmenlerin hak ettiği yeterlikte yetişmediklerini ve hak ettikleri ücreti alamadıkların düşünmekteyim. Buna bağlı olarak müdürler de hak ettikleri ücreti almamaktadırlar. Müdürlük profesyonel bir iş olması gerektiği halde sıradan bir görev olarak görülmektedir.", M4 "Kurslara ve nöbetlere devam eden öğretmen müdürün iki katı ücreti almaktadır. Ücret için bu iş yapılmaz.", M14 "Müdürlük görevi için farklı ücret uygulanıyor. Branşım itibariyle bu ücretten daha fazlasın alabilirim. Ama ücret yetersiz.", M6 "Sorumluluk çok fakat ücret tatmin edici değildir.", M18 "Kesinlikle yeterli değil. Müdür ve öğretmen arasında maaş farkı yok." şeklinde ücretin yetersizliğini belirtirken M2"Biraz iyileştirilebilir ama genel olarak yeterlidir." şeklinde ücretin kendisi için yeterli olduğunu dile getirmiştir.

\section{Görevin Toplumsal Statüsü}

Araştırmanın katılımcılarına “Müdürlük görevinin toplumsal statüsüne ilişkin düşünceleriniz nelerdir?" sorusu sorulmuş ve alınan cevaplar doğrultusunda okul müdürlerinin görevlerinin toplumsal statüsüne ilişkin iş doyumunda elde edilen temalar ve frekanslar Şekil 4'te gösterilmiştir.

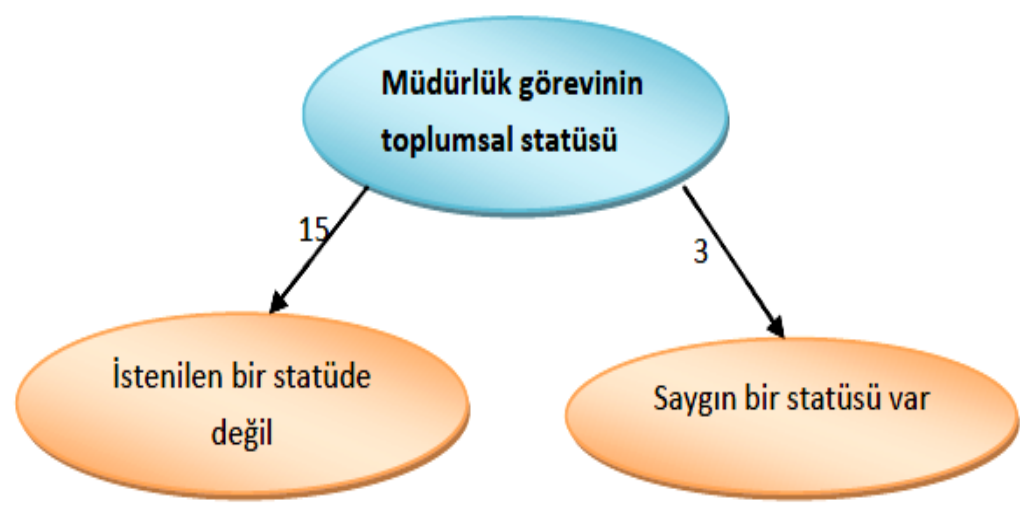

Şekil 4. Okul müdürlerinin görevlerinin toplumsal statüsüne ilişkin iş doyumuna yönelik görüşleri

Şekil 4'e göre okul müdürlerinin çoğunluğuna göre müdürlük toplumda istenilen bir statüde değil iken çok az bir kısmına göre toplumda saygın bir statüdedir. Okul müdürlerinden bazılarına göre müdürlük görevine karşı toplumda liyakate dayalı olmayan, emir eri gibi görünen, derse girmeyip maaş alan şeklinde olumsuz bir alg1 bulunmakta ve müdürlük görevinin toplumsal statüsü giderek azalmaktadır. Diğer yandan bazı okul müdürleri çevredeki insanlar tarafından kendilerine saygı duyulduğunu belirterek müdürlüğün toplumda saygın bir statüsünün olduğunu vurgulamışlardır. Okul müdürlerinden M1“Liyakata göre verilen bir görev olarak tanımlanmakta ancak insanlar arasındaki algı tam tersi bir 
durumdadır.", M6 "Velilerin emrinde bir emir eri gibi görünmektedir. Amirlerin gözünde rahat bir memur olarak görünmektedir. Halkın gözünde derse girmeyen-yan gelip yatan- koltukta oturup vatandaşın sırtından geçinen olarak görünmektedir.", M13 "Hem öğretmenliğin hem de müdürlü̈̆̈̈n toplumsal statüsünün her geçen gün düştüğ̈̈ kanaatindeyim." şeklinde müdürlük görevinin toplumdaki statüsünün olumsuz biçimde algılanmasına değinirken M14 "Kendi okulum ve okul çevrem açısından iyi bir statüye sahibim. Köyün müdürü ve imamına gayet değer verilmektedir. En azından biz o iletişimi kurmuş durumdayız." şeklinde olumlu görüşler belirtmiştir.

\section{Ödüller}

Araştırmanın katılımcılarına "Müdürlük görevinizdeki performansınız karşılığında aldığınız ödüllerin yeterliğine ilişkin düşünceleriniz nelerdir?" sorusu sorulmuş ve alınan cevaplar doğrultusunda okul müdürlerinin görevlerindeki performansları karşılığında aldıkları ödüllere ilişkin iş doyumunda elde edilen temalar ve frekanslar Şekil 5 'te gösterilmiştir.

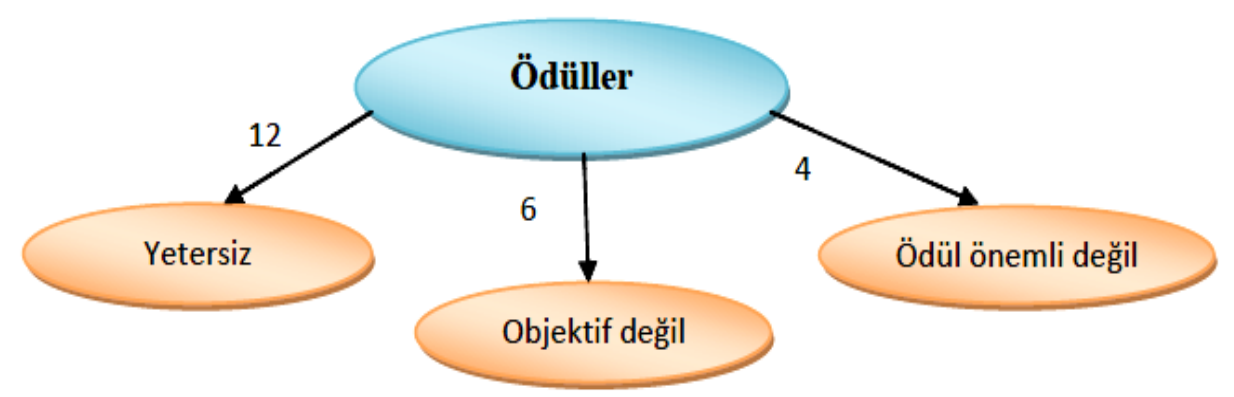

Şekil 5. Okul müdürlerinin görevlerindeki performansları karşılığında aldıkları ödüllere ilişkin iş doyumuna yönelik görüşleri

Şekil 5’e göre okul müdürlerinin çoğunluğu görevlerindeki performansları karşılığında aldıkları ödüllerin yetersiz olduğunu, bazıları ödüllendirmenin objektif olmadığını, bazıları ise herhangi bir ödül beklentileri olmadığını ve ödülün önemli olmadığını belirtmiştir. Okul müdürlerinden M4 "Ödül çalışana değil adamı olana verilir." ve M14 "Maalesef ödül yönetmeliği sübjektif kriterlerden oluşmaktadır. O sübjektif kriterler de sübjektif uygulanmaktadır." şeklinde ödüllendirmelerin objektif olmadığını belirtmişlerdir. M6 "Stresi çok olan bir görev ancak ödülü yoktur. İş yükü yoğunluğu, stresi ve sorumluluğu yüksek bir görev olduğundan ciddi ödüller olmalıdır." şeklinde ödüllerin yetersiz olduğunu ifade etmiştir. M13“Kurumumuz maalesef bu konuda ya hiç ödüllendirme yapmıyor ya da ödüllendirme adaletsiz oluyor." şeklinde ödüllendirmenin yetersizliğini ve objektif olmadığını vurgulamıştır. Diğer yandan M7 ise "Herhangi bir ödül aldığımı hatırlamıyorum. Bu işi yaptığımdan dolayı ödül beklentim de yoktur." şeklindeki görüşüyle ödüllendirmenin yetersizliğini ve ödül beklentisinin olmadığını belirtmiştir. M15 “Ödül için bu iş yapılmaz." ve M17 “ỉki kez teşekkür aldım ancak benim için önemli olan ödül yaptığım işin olumlu dönütlerini almak" şeklinde ödüllerin kendileri için önemli olmadığını belirtmişlerdir. 


\section{Kendini Geliştirme ve Yükselme Olanakları}

Araştırmanın katılımcılarına "Müdürlük görevinizde kendinizi geliştirme ve yükseltme olanaklarının yeterliğine ilişkin görüşleriniz nelerdir?" sorusu sorulmuş ve alınan cevaplar doğrultusunda okul müdürlerinin görevlerinde kendilerini geliştirme ve yükselme olanaklarına ilişkin iş doyumunda elde edilen temalar ve frekanslar Şekil 6'da gösterilmiştir.

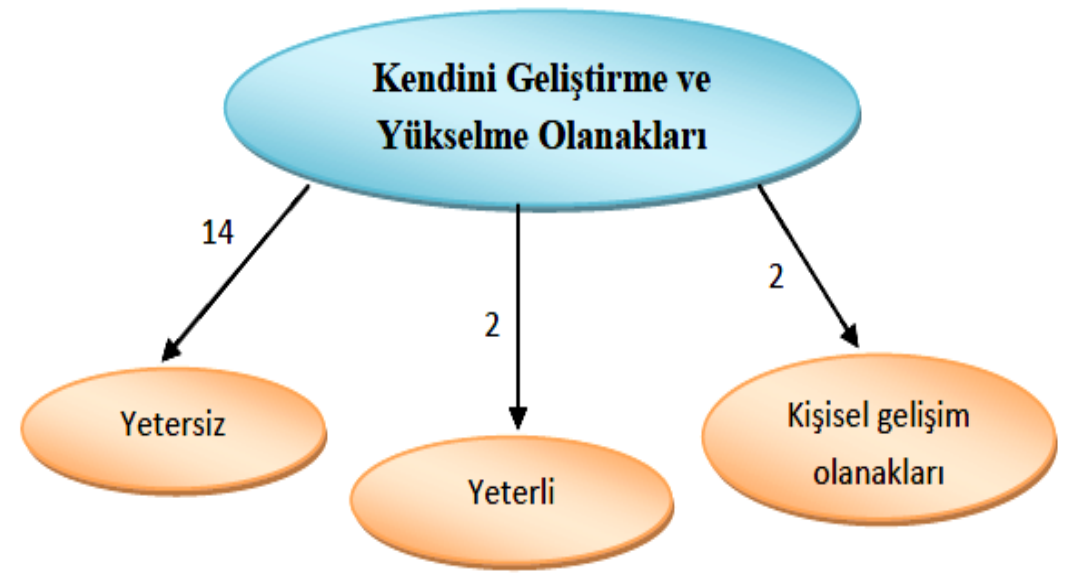

Şekil 6. Okul müdürlerinin görevlerinde kendilerini geliştirme ve yükselme olanaklarına ilişkin iş doyumuna yönelik görüşleri

Şekil 6'ya göre okul müdürlerinin çoğunluğu görevlerinde kendilerini geliştirme ve yükselme olanaklarının yetersiz olduğunu, bazıları yeterli olduğunu, bazıları da kişisel açıdan kendilerini geliştirme olanaklarının bulunduğunu belirtmişlerdir. Yetersiz olduğunu belirten okul müdürleri hizmet içi eğitimlerin uygun şekilde gerçekleştirilmediğini ve yetersizliğini, iş yoğunluğunun kendilerini geliştirmelerine engel olduğunu, kademelere göre müdürlüğün cazip hale getirilmesi gerektiğini ve olanakların objektif olmadığını belirtmişlerdir. Okul müdürlerinden M1“Yeterli değil. Verilen eğitimlerde yaş grubu, iş yoğunluğu ve yorgunluk dikkate alınmıyor. Uygun ortam hazırlanmıyor." ve M3“Yetersizdir. İşinde uzman olan kişilerle isteğe bağlı yılda en az iki defa kısa süreli seminer verilmesi iyi olur." şeklinde hizmet içi eğitimlerin uygun olmadığını ve yetersizliğini belirtmişlerdir. M4 "Okul işleri ile uğraşmaktan kendimize ve ailemize zaman ayıramıyoruz" ve M9 "Asli görevlerin yapılamadığı ve görevimiz dışındaki olumsuzluklarla zaman geçtiği için ARGE'ye yönelik çalışma zamanı bulamıyoruz." şeklinde iş yoğunluğundan kendilerini geliştiremediklerini ifade etmişlerdir. M14 "Geliştirme ve yükselme mülakata dayalı olduğundan öyle bir imkân görülmemektedir" şeklinde geliştirme ve yükselmenin objektif olarak gerçekleştirilmediğini belirtmiştir. M18 ise "Bu görevi yürütürken mevzuatı öğrendim, insanları yönetmeyi başardım, empati kurmayı öğrendim. Halkla ilişkiler, ekonomi, esnaf iletişimi gibi daha pek çok şey öğrendim." şeklinde müdürlük görevinin kendisini çeşitli konularda geliştirdiğini belirtmiştir.

\section{Astlar}

Araştırmanın katılımcılarına "Görev yaptı̆̆ınız okuldaki astlarınıza ilişkin hoşnutluklarınız nelerdir?" ve "Görev yaptığınız okuldaki astlarınıza ilişkin hoşnutsuzluklarınız nelerdir?" 
soruları sorulmuş ve alınan cevaplar doğrultusunda okul müdürlerinin astlarına ilişkin iş doyumunda elde edilen temalar ve frekanslar Şekil 7'de gösterilmiştir.

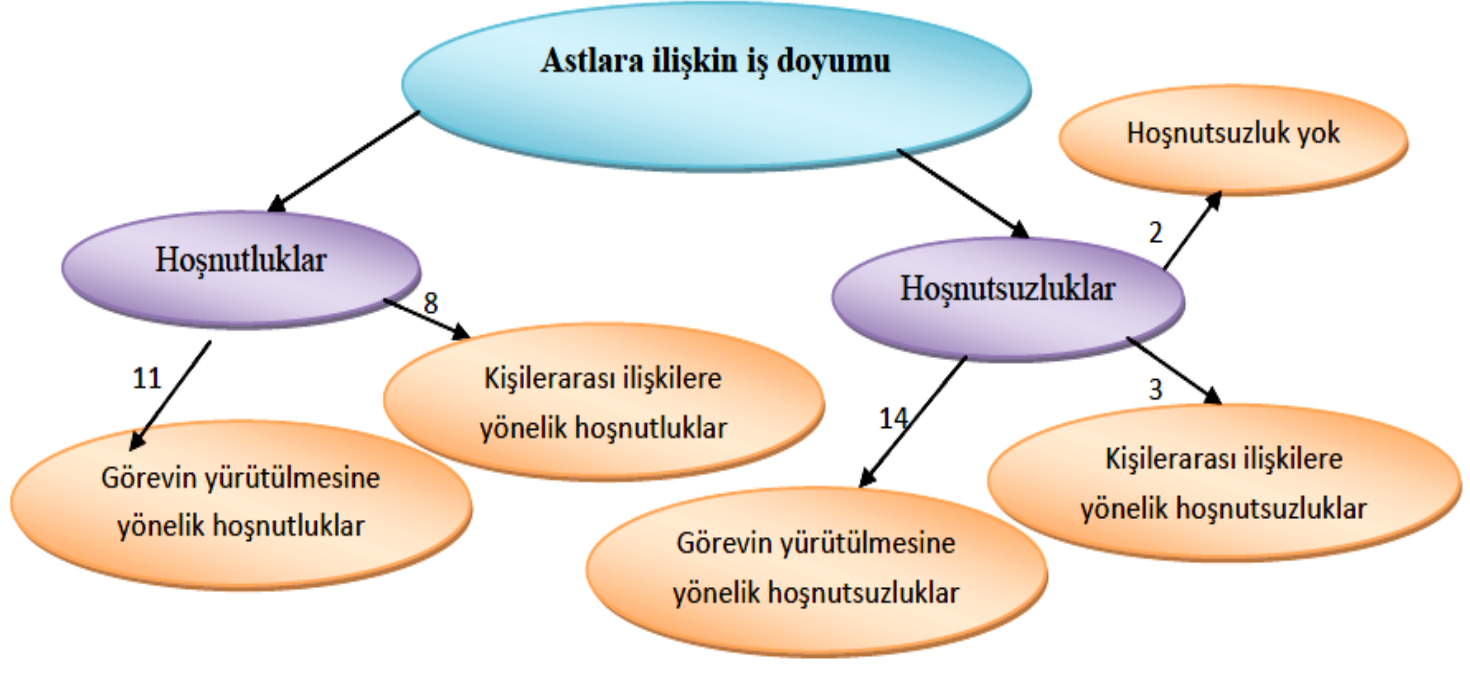

Şekil 7. Okul müdürlerinin astlarına ilişkin iş doyumuna yönelik görüşleri

Şekil 7'ye göre okul müdürlerinin astlarına ilişkin görevin yürütülmesi ve kişilerarası ilişkiler açısından hoşnutluklarının yanı sıra hoşnutsuzluklarının da olduğu belirlenirken bazı okul müdürlerinin herhangi bir hoşnutsuzluğu bulunmamaktadır. "Görevin yürütülmesine yönelik hoşnutluklar" temasına göre okul müdürlerinin çoğunluğu astlarında görev bilincinin olması, görevlerini severek yapmaları, işbirlikçi olmaları ve mesleki yeterliklerinin olması açısından astlarından hoşnutturlar. "Görevin yürütülmesine yönelik hoşnutsuzluklar" temasına göre okul müdürlerinin çoğunluğu astlarının görevlerini aksatmaları, kendilerini geliştirmemeleri, sorun çözümüne ortak olmamaları, sorumluluktan kaçınmaları, rapor almaları, bilerek işi yavaşlatmaları ve mesleki alanda yetersizlikleri açısından astlarından hoşnut değillerdir. "Kişilerarası ilişkilere yönelik hoşnutluklar" temasına göre okul müdürlerinden bazıları astlarının samimiyet, saygı, sevgi, memnuniyetlerini belirtme, iletişim kurabilme ve kültürel benzerlik açısından astlarından hoşnutturlar. "Kişilerarası ilişkilere yönelik hoşnutsuzluklar" temasına göre bazı okul müdürleri farklı amaçlar için okul müdürünün etrafında ekip kurmaya çalışmaları, iletişime açık olmama ve beklentileri karşılanmadığında bunu olumsuz şekilde ifade etmeleri açısından astlarından hoşnut değillerdir.

Okul müdürlerinden M3 "Görevinin bilincinde olanlarla çalışmaktan hoşnut olurum. Bilip uygulanınca da daha çok hoşuma gider. Çalışanların bilerek işlerini yavaşlatmaları, öğrenme isteğinde bulunmamalar bende hoşnutsuzluk oluşturuyor." ve M6 "Görevini tam zamanında yapanlar ve gerekli donanıma sahip olanlar beni mutlu ediyor. Görevinde lakayt davrananlar, nöbetini zamanında tutmayanlar, sınıf defterini zamanında doldurmayanlar, öğrenciler için gerekli motivasyonu arttırıcı uygulama yapmayanlar beni mutsuz ediyor." şeklinde astlarına ilişkin görevlerinin yürütülmesiyle ilgili hoşnutluklarını ve hoşnutsuzluklarını belirtmişlerdir. M18 "Okulumuzda ekip ruhu var, herkes birbirine yardımo oluyor, birbirini tamamlıyor ve samimidirler. Ancak çalışmak istemeyen insanlar beni zorluyor. Öğretmen rapor kullandı̆̆ında sıkıntı yaşanıyor. Yeniliklere açık olmayan insanları değiştirmek çok zor." şeklinde hem göreve hem de kişilerarası ilişkilere yönelik 
hoşnutluklarını belirtirken sadece göreve yönelik hoşnutsuzluklarını vurgulamıştır. M4 ise "En iyi yer okulum. Çok samimi, mesleğin gereğini yerine getiren ilişkilerimiz mevcuttur. Astlar konusunda herhangi bir sıkıntı yaşamamaktayım." şeklinde astlarına yönelik hem görevin gerçekleştirilmesi hem de insan ilişkileri açısından hoşnutluklarını belirtirken herhangi bir hoşnutsuzluğunun olmadığını belirtmiştir.

\section{Çalışma Koşulları}

Araştırmanın katılımcılarına "Görev yaptı̆̆ınız okulun çalışma koşullarına ilişkin hoşnutluklarınız nelerdir?" ve "Görev yaptığınız okulun çalışma koşullarına ilişkin hoşnutsuzluklarınız nelerdir?" soruları sorulmuş ve alınan cevaplar doğrultusunda okul müdürlerinin görev yaptıkları okulun çalışma koşullarına ilişkin iş doyumunda elde edilen temalar ve frekanslar Şekil 8'de gösterilmiştir.

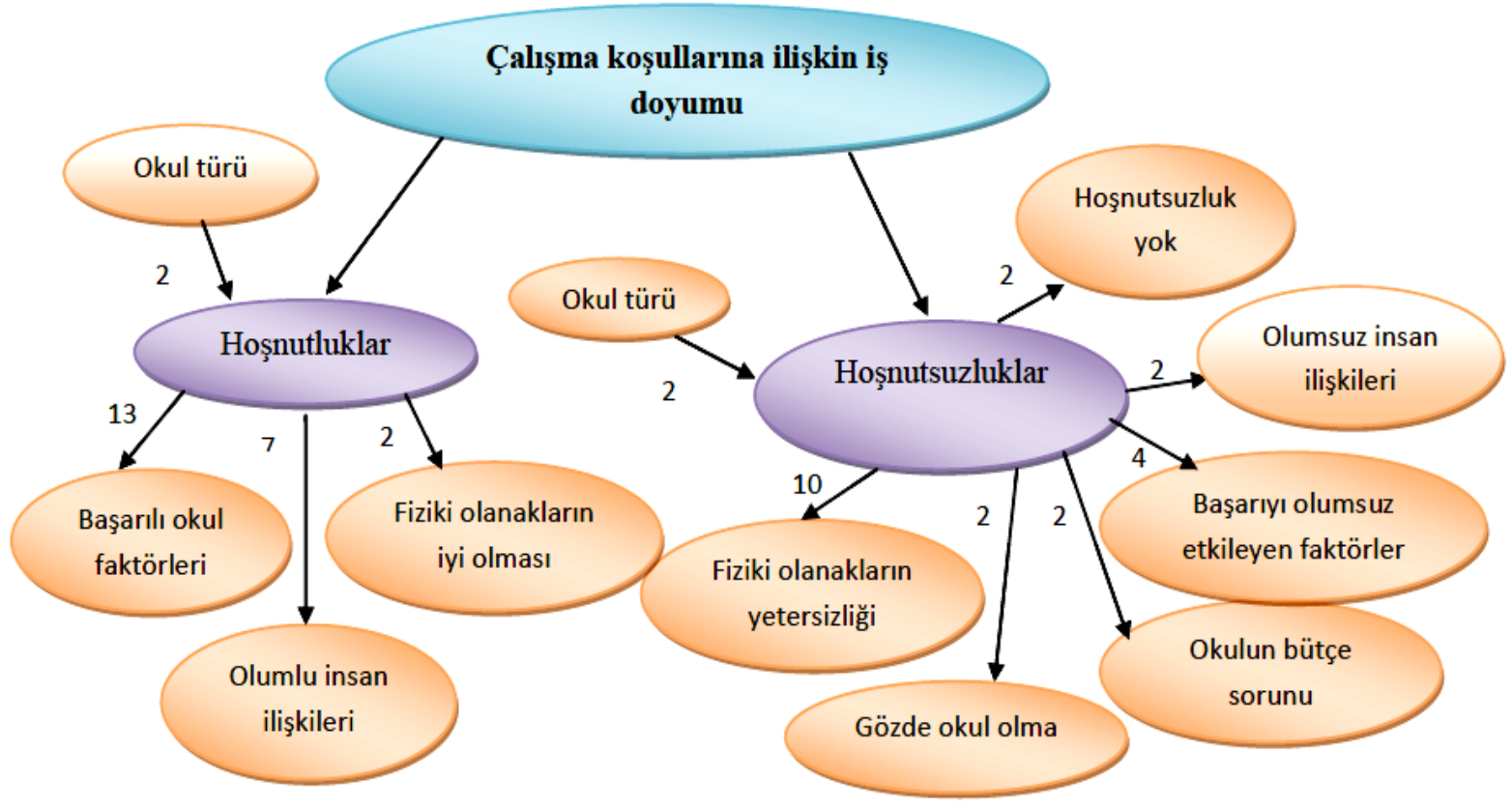

Şekil 8. Okul müdürlerinin görev yaptıkları okulun çalışma koşullarına ilişkin iş doyumuna yönelik görüşleri

Şekil 8'e göre okul müdürlerinin okulun çalışma koşullarına ilişkin hoşnutlukları "Başarılı okul faktörleri, Olumlu insan ilişkileri, Fiziki olanakların iyi olması ve Okul türü" temaları; hoşnutsuzlukları "Fiziki olanakların yetersizliği, Başarıyı olumsuz etkileyen faktörler, Gözde okul olma, Okulun bütçe sorunu, Olumsuz insan ilişkileri ve Okul türü" temaları altında toplanmıştır. Bununla birlikte okul müdürlerinden bazıları okulun çalışma koşullarına ilişkin hoşnutsuzluklarının olmadığını belirtmiş̧lerdir.

"Başarılı okul faktörleri" temasındaki görüşlere göre okul müdürlerinin çoğunluğu tarafından başarılı ve tercih edilen bir okul olmak; öğrencilerin derslere duyarlı olması; iyi bir öğrenci profilinin bulunması; velilerin duyarlı olması ve okul ile işbirliği yapmaları; çalışanların nitelikli, kendilerini geliştiren, üretken, genç, görev bilincinde, fedakâr olmaları, 
işbirliği ve uyum içerisinde çalışmaları çalışma koşullarıyla ilgili hoşnutluklar olarak belirtilmiştir. Okul müdürlerinden M1 “Çalışanlarm çoğunun genç denilecek yaşta olmaları, fikir üretme noktasında istekli olmaları ... hoşnut olduğum durumlardır.", M6 "İyi bir akademik kadroya sahip olmaktan, öğrencilerin bir kısmının derslere duyarl olmasından ... hoşnutum.", M12 "...Öğrenci profili bakımından iyi bir okul olmamız beni mutlu ediyor.", M13 "Büyük oranda çalışanlar arasında uyum ve ahenk bulunması, çalışanların sürekli olarak kendilerini yenilemeleri ve fedakâr olmaları..." şeklinde başarılı okul faktörlerinden hoşnutluklarını dile getirmişlerdir.

"Olumlu insan ilişkileri" temasına göre bazı okul müdürleri okulda olumlu bir iletişim olmasından, aile ortamının oluşturulmuş olmasından, çalışanların birbirleriyle samimi ilişkiler içerisinde olmasından, mutlu bir ortamın oluşmasından, öğrenci-öğretmen-veli sorununun olmamasından hoşnutturlar. Okul müdürlerinden $\mathrm{M} 1$ “. . çalışma ortamının büyük bir aileye dönüşmesi..." M6 “.. bazı okullarda yaşanan öğrenci-öğretmen-veli sorunlarının okulumda yaşanmamasından hoşnutum." M18 "Sıcak, samimi, huzurlu bir ortamın olması..." şeklinde okulda olumlu ilişkilerin bulunması açısından hoşnutluklarını belirtmişlerdir.

"Fiziki olanakların iyi olması" temasına göre okul müdürlerinden bazıları okulun pansiyonlu olmasının avantajlarından, fiziki yapının iyi olmasından ve okula ulaşım sorununun olmamasından hoşnutturlar. Okul müdürlerinden M4 "Okulun pansiyonlu olmasinın güzel yanları bulunmakta...", ve M12 "Okulumuz fiziki yapı ve okula ulaşım açısından iyi sayılır." şeklinde okuldaki fiziki koşullardan hoşnutluklarını dile getirmişlerdir.

"Okul türü" temasına göre okul müdürlerinden bazıları okulun meslek lisesi olmasından dolayı oluşan sorunları gidermekten ve okulun anaokulu olmasından dolayı okulda küçük yaştaki çocukların ve kadın personel sayısının daha fazla olmasının okulda olumlu bir ortam oluşturmasından hoşnutturlar. Okul müdürlerinden M8 "Mesleki ve Teknik Anadolu liselerinin öğrenci profili ve toplum algısı bazı açmazlar yaratıyor. Bunlara çözüm üretmek haz veriyor.", M18 "... küçük çocukların da olması olumlu bir hava oluşturuyor. Kadın personelin çok olması olumlu etki oluşturuyor." şeklinde okul türünün verdiği hoşnutları vurgulamışlardır.

"Fiziki olanakların yetersizliği” temasına göre okul müdürlerinin çoğunluğu ikili öğretim yapmaktan, aynı binada iki okulun eğitim-öğretim yapmasından, okulun fiziki koşullarının yetersizliğinden, okulda sosyokültürel etkinliklerin yetersizliğinden, hizmetli eksikliğinden ve okula ulaşım sorununun bulunmasından hoşnut değillerdir. Okul müdürlerinden M1 "İkili öğretim yapan bir okulda çalışıyor olmak, farkh bir eğitim kurumu ile aynı binada çalışmak ... hoşnut olmadığım durumlardandır.", M6 "Yeterli sportif-kültürel-sosyal donanım ve fiziki yetersizlikten, okulun şehrin dışında olması nedeniyle ulaşım sorunu yaşamaktan ... hoşnut değilim." ve M14 "Fiziki aksaklıkların giderilme yönteminden rahatsızım. Sorunlar sağlıklı bir şekilde giderilememektedir." şeklinde okulun fiziki olanaklarının yetersizliğinden dolayı hoşnutsuzluklarını belirtmişlerdir.

"Başarıyı olumsuz etkileyen faktörler" temasına göre bazı okul müdürleri velilerin duyarsızlığından, öğrencilerin sorumsuzluğundan, okulda gelişime kapalılığın ve bireysel çalışmanın bulunmasından hoşnut değillerdir. Okul müdürlerinden M6 “ ... velilerin duyarsızh̆̆ından ve öğrencilerin bir kısmının sahip olduklarının kıymetini bilmemesinden hoşnut değilim.", M12 "Velilerin gerekli duyarlılı̆ga sahip olmamaları ve yapılan etkinliklere gerekli desteği göstermemeleri beni mutsuz ediyor." şeklinde okuldaki başarıyı olumsuz etkileyen faktörlerden dolayı hoşnutsuzluklarını dile getirmişlerdir. 
"Gözde okul olma" temasına göre okul müdürlerinin bazıları gözde okul olmaları nedeniyle daha dikkatli ve daha fazla çalışmak zorunda olmaktan, okula aşırı talep olduğundan öğrenci sayısının fazlalığından hoşnut değillerdir. Okul müdürlerinden M4 "Gözde okul olmanın gerektirdiği yüksek sorumluluk fazla dikkatli ve daha çok çalışmamızı gerektiriyor." ve M9 "Okula aşırı yoğun bir talep bulunmakta ve bu da okuldaki kalabalıklı̆̆g artırarak olumsuzluk oluşturmaktadır." şeklinde gözde okul olmanın oluşturduğu olumsuzluklara ilişkin hoşnutsuzluklarını belirtmişlerdir.

"Okulun bütçe sorunu" temasına göre okul müdürlerinin bazıları okulun ödeneklerinin yetersizliğinden ve velilerden aidat almaktan hoşnut değillerdir. M18 “... ödenekler yeterli olmuyor. Aidat almak ise veliyle sorunların yaşanmasına neden oluyor." şeklinde okulun bütçe sorunundan dolayı hoşnutsuzluğunu dile getirmiştir.

"Olumsuz insan ilişkileri" temasına göre bazı okul müdürleri aynı binada olan farklı okul çalışanlarının farklı bakış açısına sahip olmalarından ve okulda çalışanlar arasında uyumsuzluğun bulunmasından hoşnut değillerdir. Okul müdürlerinden M1 “... çalışmak zorunda kaldığımız diğer kurumun çalışanları ile farklı bakış açısına sahip olmak hoşnut olmadı̆̆ım durumlardandır." ve M13 "Ender de olsa çalışanlar arasında uyumsuzluğun oluşması rahatsız olduğum bir durum." şeklinde okuldaki olumsuz insan ilişkilerinden hoşnutsuzluklarını vurgulamışlardır.

"Okul türü" temasına göre bazı okul müdürleri anaokulu olduğundan küçük yaştaki öğrencilerin risk oluşturabilmesinden, meslek lisesi olması nedeniyle hem Milli Eğitim Sistemi' nde alan türüne olumsuz bakış açısının bulunmasından ve toplumda meslek liselerine karşı olumsuz bir bakış açısının olmasından hoşnut değillerdir. Okul müdürlerinden M8“... Milli Ĕ̆itim Sistemi'nin alan türüne bakış açısı ve toplumun olumsuz algısı beni rahatsız ediyor." ve M18 "Küçük çocuklar risk oluşturuyor. Hijyen ve beslenme çok önemli, çok dikkat etmek gerekiyor." şeklinde okul türleri nedeniyle oluşan hoşnutsuzluklarını belirtmişlerdir.

\section{Tartışma, Sonuç ve Öneriler}

$\mathrm{Bu}$ araştırmada iş ve çalışma ortamı ile ilgili etkenler açısından okul müdürlerinin iş doyumuna ilişkin ayrıntılı bilgiler elde edilmiştir. Araştırmada müdürlük görevinin faydalı olabilme, yönetme ve bağımsız çalışma imkânı sağlamasının okul müdürlerini hoşnut ettiği belirlenmiştir. Benzer şekilde Köseoğlu (2017) yöneticilerin çoğunluğunun tek başına çalışma, başkaları için bir şeyler yapabilme, kendi kararlarını serbestçe uygulama olanağı ve kendi yöntemlerini kullanabilme şansı vermesi bakımından memnun olduğu sonucuna ulaşmıştır. Maforah'ın (2015) çalışmasında ise müdürleri görevlerinde tutan etkenin içsel etken olan genç beyinlerle uğraşmak, onları geliştirmek ve her öğrencinin iyi bir şekilde ilerlemesinin sevinci olduğu belirlenmiştir. O halde okul müdürlerinin müdürlük görevinin niteliği açısından içsel bir doyum yaşadıkları söylenebilir.

Araştırma bulgularına göre görev-yetki ve sorumluluk dengesizliği, bürokrasi, personel yönetimi sorunları, okulun bütçe sorunu, öğrenci yönetimi sorunları, üst yönetimin olumsuz tutum ve davranışları, velilerle yaşanan sorunlar okul müdürlerinin hoşnut olmadıkları durumlardır. Bu bulguya dayanılarak okul müdürlerinin görevlerini gerçekleştirirken yaşadıkları sorunların iş doyumlarını azaltabileceği söylenebilir. Diğer yandan okul müdürlerinin okulda eğitim-öğretim işleri, personel yönetimi, öğrenci yönetimi, okulun 
güvenliği, resmi yazışmalar vb. pek çok farklı görevi bulunmaktadır. Bununla birlikte okul müdürlerinden beklenen rollerin değişerek çeşitlendiği ve iş yükününün arttığı belirtmektedir (Balyer, 2012). Okul müdürlerinin iş yükü strese neden olurken (Demirkasımoğlu, 2015) artan iş yükü (Keser, 2006) ve iş stresi (Acar, 2019) iş doyumunu azaltmaktadır.

Okul müdürlerinin çok az bir kısmı için aldıkları ücret yeterli iken çoğunluğu için yetersizdir. Benzer şekilde Maforah (2015) okul müdürlerinin Köseoğlu (2017) ise okul yöneticilerinin çoğunluğunun ücretlerinden memnun olmadıklarını belirlemiştir. Ücretten memnun olan yöneticilerin iş doyumunun daha fazla olması (Akbaş, 2016) sonucu elde edilen bulgu bu bulgu okul müdürlerinin çoğunluğunun aldıkları ücret konusunda iş doyumsuzluğu yaşadıklarını göstermektedir.

Okul müdürlerinin çoğunluğuna göre müdürlük toplumda istenilen bir statüde olmayıp toplumda müdürlük görevi ile ilgili olumsuz algılar mevcuttur. Bununla birlikte müdürlük görevinin toplumsal statüsünün gittikçe düştüğü de belirtilmektedir. Bu bulgu okul müdürlerinin çoğunluğunda görevlerinin toplumsal açıdan önemsenmediği düşüncesinin olduğunu göstermektedir. Oysa iş doyumunun oluşabilmesi için görevin toplumda önemsenmesi gerekmektedir (Başaran, 2008, s. 267). Bu açıdan okul müdürlerinin çoğunluğunun müdürlük görevinin toplumsal statüsü açısından iş doyumsuzluğu yaşadıkları söylenebilir. Bununla birlikte müdürlük görevinin toplumda saygınlık oluşturduğunu belirten bazı okul müdürleri de bulunmaktadır.

Okul müdürlerinin çoğunluğuna göre aldıkları ödüller yetersiz iken bazılarına göre ödüllendirmeler objektif değildir. Bazı okul müdürleri ciddi ödüllendirmelerin yapılması gerektiğini belirtmişlerdir. Bu sonuç bazı okul müdürlerinin performansları karşılığında ödül beklentisi içerisinde olduğunu ve bu ödüllerin verilmesinde belirli objektif kriterlerin gözetilmesi gerektiğini belirtmektedir. Bu açıdan okul müdürlerinin çoğunluğunun aldıkları ödüller açısından iş doyumsuzluğu yaşadıkları söylenebilir. Benzer şekilde Maforah (2015) okul müdürlerinin çoğunluğuna göre performansları karşılığında yeterli ödüllendirmenin yapılmadığını belirlemiştir. Ödül alan okul müdürlerinin iş doyumlarının daha yüksek olduğu belirlenmesine (Başer ve Özel, 2013) rağmen bu araştırmadaki bazı okul müdürlerinin herhangi bir ödül beklentisi içerisinde olmayıp ödülleri önemsememeleri bu okul müdürleri için ödülün iş doyum etkeni olarak görülmediğini gösterebilir.

Okul müdürlerinin çoğunluğu görevlerinde kendilerini geliştirme ve yükselme olanaklarının yetersiz olduğunu, bazıları ise yeterli olduğunu belirtmişlerdir. Yetersiz olduğunu belirten okul müdürleri hizmet içi eğitimlerin yetersizliğini ve uygun şekilde gerçekleştirilmediğini, iş yoğunluğunun kendilerini geliştirmelerine engel olduğunu, kademelere göre müdürlüğün cazip hale getirilmesi gerektiğini ve olanakların objektif olmadığını belirtmişlerdir. Bu açıdan okul müdürlerinin çoğunluğunun görevlerinde kendilerini geliştirme ve yükselme açısından iş doyumsuzluğu yaşadıkları söylenebilir. Benzer şekilde Köseoğlu (2017) terfi olanakları bakımından yöneticilerin yarısına yakın bir kısmının memnun olmadığını belirlemiştir. Bununla birlikte bazı okul müdürleri müdürlük görevinin mevzuat bilgisi, insan ilişkileri, yönetme gibi birtakım beceriler açısından bireyleri geliştirdiğine değinmiştir.

Okul yöneticilerinin çalışma arkadaşları bakımından çoğunluğunun memnun olduğu belirlenmiştir (Köseoğlu, 2017). Bu araştırmada daha ayrıntılara inilerek okul müdürlerinin astlarına yönelik olarak hangi açlardan iş doyumu ve iş doyumsuzluğu yaşadıkları ortaya konulmuştur. Araştırmada okul müdürlerinin astlarına ilişkin görevin yürütülmesi ve 
kişilerarası ilişkiler açısından hoşnutluklarının yanı sıra hoşnutsuzluklarının da olduğu belirlenirken bazı okul müdürlerinin astlarına yönelik herhangi bir hoşnutsuzluğu bulunmamaktadır. Bu bulgu okul müdürlerinin astlarının görevlerini gerçekleştirmesinin ve kişilerarası ilişkilerinin iş doyumunu etkilediğini gösterebilmektedir. Görevlerini gerçekleştirmesine yönelik olarak astlarda görev bilincinin olması, görevlerini severek yapmaları, işbirlikçi olmaları ve mesleki yeterliklerinin bulunması okul müdürlerinin iş doyumunu artıran etkenlerdir. Astlarının görevlerini aksatmaları, kendilerini geliştirmemeleri, sorun çözümüne ortak olmamaları, sorumluluktan kaçınmaları, rapor almaları, bilerek işi yavaşlatmaları ve mesleki alanda yetersiz olmaları okul müdürlerinin iş doyumunu azaltan etkenlerdir. Kişilerarası ilişkilere yönelik olarak astlarının samimiyet, sayg1, sevgi, memnuniyetlerini belirtme, iletişim kurabilme ve kültürel benzerlik özelliklerinin bulunması okul müdürlerinin iş doyumunu artıran etkenlerdir. Astların farklı amaçlar için okul müdürünün etrafında ekip kurmaya çalışmaları, iletişime açık olmamaları ve beklentileri karşılanmadığında bunu olumsuz şekilde ifade etmeleri okul müdürlerinin iş doyumunu azaltan etkenlerdir.

$\mathrm{Bu}$ araştırmada çalışma ortamında başarılı okul faktörlerinin, olumlu insan ilişkilerinin ve iyi fiziki olanakların bulunmasının okul müdürlerinde hoşnutluk oluşturduğu; başarıyı olumsuz etkileyen faktörlerin, yetersiz fiziki olanakların ve olumsuz insan ilişkilerinin okul müdürlerinde hoşnutsuzluk oluşturduğu belirlenmiştir. Diğer yandan okul türünün okul müdürlerinde hem hoşnutluk hem de hoşnutsuzluk oluşturduğu sonucuna ulaşılmıştır. Benzer şekilde Hulpia ve Devos tarafından yapılan çalışmada (2009) genel eğitim veren okullardaki yöneticilerin iş doyumunun mesleki ya da teknik eğitim veren okullardaki yöneticilerden daha düşük olduğu belirlenmiştir. Postma'ya (2019) göre ilköğretim okulu müdürleri ortaokul müdürlerinden daha fazla iş doyumuna sahiptir. Baltacı'ya (2017) göre kamu okullarındaki müdürlerin iş doyumu özel okullardaki müdürlerden daha fazladır. Buna karşın Ağıroğlu-Bakır ve Aslan'a (2017) göre okul türü okul müdürlerinin iş doyumunu etkilememektedir.

Araştırma sonucuna göre okul müdürlerinin çoğunluğu ödül, müdürlük görevinin toplumsal statüsü, ücret, kendini geliştirme ve yükselme açısından iş doyumsuzluğu yaşamaktadır. Bu açıdan okul müdürlerinin görevleri karşılığında aldıkları ek ders sayısı artırılarak ücretlerinde artış yapılabilir. Verilecek ödüllerde objektif kriterlerin net olarak belirlenmesi ve bu doğrultuda başarı gösteren okul müdürlerinin ödüllendirilmesi iş doyumunu artırabilir. Okul müdürlerinin kendilerini geliştirmeleri için sıklıkla hizmet içi eğitimlerin verilmesi ancak bu eğitimlerin alanında uzman akademisyenler tarafından ve okulların tatil zamanlarında verilmesi iş doyumunu artırabilir. Okul müdürlerinin görevlerinde yükselmelerini sağlamak amacıyla müdürlük kariyer basamakları oluşturulabilir. Müdürlerin toplumsal saygınlığının artırılması için önemli başarılar edinen okul müdürlerin başarılarını topluma tanıtma çalışmaları yapılabilir. Araştırmadan elde edilen bir diğer sonuç okul müdürlerinin görevin niteliklerine, astlarına ve çalışma koşullarına ilişkin hoşnutluklarının yanı sıra hoşnutsuzluklarının da bulunmasıdır. Okul müdürlerinin yaşadıkları sorunların iş doyumsuzluğuna neden olduğu hususuna dikkat edilerek bu sorunların azaltılması için gerekli desteğin sağlanması iş doyumunu artırabilir. Astların hem görevin gerçekleştirilmesi hem de kişilerarası ilişkiler açısından okul müdürlerinin beklentileri doğrultusunda davranışlar sergilemeleri okul müdürlerinin iş doyumunu artırabilir. Okulun fiziki olanaklarının geliştirilmesi için gerekli desteğin sağlanması müdürlerin iş doyumunu artırabilir. Benzer araştırmalar farklı illerde gerçekleştirilerek bu araştırma sonuçlarıyla 
karşılaştırılabilir. Okul müdürlerinin iş doyumlarının öğretmenlerin iş doyumlarını nasıl etkilediğine yönelik araştırmalar yapılarak alanyazına katkı sunulabilir.

\section{Teşekkür ve Bilgilendirme}

Bu makale 3-5 Mayıs 2018 tarihinde Alanya'da gerçekleştirilen 4. Uluslararası Eğitim Bilimleri Sempozyumu'nda sözlü olarak sunulan bildirinin gözden geçirilmiş halidir.

\section{Kaynakça}

Acar, M. (2019). Okul yöneticilerinin iş tatmini, duygusal emek ve iş stresi arasındaki ilişki: Konya ili üzerine bir araştırma. Yüksek lisans tezi, Necmettin Erbakan Üniversitesi, Sosyal Bilimler Enstitüsü, Konya.

Ağıroğlu-Bakır, A., \& Aslan, M. (2017). Examining the relationship between principals' organizational loneliness and job satisfaction levels. European Journal of Education Studies, 3(6), 50-71.

Akbaş, M. A. (2016). Özel eğitim okullarında yöneticilerin iş doyumunun incelenmesi: İzmir bölgesi uygulaması. Yüksek lisans tezi, Türk Hava Kurumu Üniversitesi Sosyal Bilimler Enstitüsü.

Avşaroğlu, S., Deniz, M. E.,\& Kahraman, A. (2005). Teknik öğretmenlerde yaşam doyumu iş doyumu ve mesleki tükenmişlik düzeylerinin incelenmesi. Selçuk Üniversitesi Sosyal Bilimler Enstitüsü Dergisi, 14, 115-129.

Aydın, A., Sarıer, Y., \& Uysal, Ş. (2013). Okul müdürlerinin liderlik stillerinin, öğretmenlerin örgütsel bağlllı̆̆ına ve iş doyumuna etkisi. Kuram ve Uygulamada Ĕ̆itim Bilimleri, 13(2), 795811.

Aziri, B. (2011). Job satisfaction: A literature review. Management Research E Practice, 3(4), 7786.

Baltacı, A. (2017). Okul müdürlerinin iş doyumları ile öz yeterlik algıları arasındaki ilişki. Ihlara Ĕ̆itim Araştırmaları Dergisi, 2(1), 49-76

Balyer, A. (2012). Çağdaş okul müdürlerinin değişen rolleri. Ahi Evran Üniversitesi Kırşehir Eğitim Fakültesi Dergisi, 13(2), 75-93.

Başaran, İ. E. (2008). Örgütsel davranış insanın üretim gücü. Ankara: Ekinoks.

Başer, M. U., \& Özel, B. U. A. (2013). İlköğretim okulu müdürlerinin iş doyum düzeyleri. eUluslararası Eğitim Araştırmaları Dergisi, 4(1), 47-62.

Büyüköztürk, Ş., Kılıç Çakmak, E., Akgün, Ö. E., Karadeniz, Ş., \& Demirel, F. (2016). Bilimsel araştırma yöntemleri. Ankara: Pegem Akademi.

Crossman, A., \& Harris, P. (2006). Job satisfaction of secondary school teachers. Educational Management Administration E Leadership, 34(1), 29-46.

Çekmecelioğlu, H. (2006). İş tatmini ve örgütsel bağlllık tutumlarının işten ayrılma niyeti ve verimlilik üzerindeki etkilerinin değerlendirilmesi: Bir araştırma. Iş̧, Güç Endüstri İlişkileri ve Insan Kaynakları Dergisi, 8(2), 153-168. 
Çırakoğlu, H. (2010). Örgütsel özdeşleşme ve iş doyumu ilişkisi. Yüksek lisans tezi, Dokuz Eylül Üniversitesi, Sosyal Bilimler Enstitüsü, İzmir.

Demirkasımoğlu, N. (2015). Kamu okulu yöneticilerinin iş yükü kaynakları, sorunları ve yönetilebilirliği. Route Educational and Social Science Journal, 2(4), 345-364.

Dikmen, A. A. (1995). İş doyumu ve yaşam doyumu ilişkisi. Ankara Üniversitesi Siyasal Bilgiler Fakültesi Dergisi, 50(3-4), 115-140.

Faragher, E. B., Cass, M., \& Cooper, C. L. (2005). The relationship between job satisfaction and health: a meta-analysis. Occupational and Environmental Medicine, 62(2), 105-112.

Fırat, Z. M., \& Cula, S. (2016). İş-aile çatışması, aile-iş çatışması ve iş doyumunun öğretmenlerin yaşam doyumu üzerindeki etkisi. Başkent University Journal of Education, 3(2), 146-155.

Hulpia, H., \& Devos, G. (2009). Exploring the link between distributed leadership and job satisfaction of school leaders. Educational Studies, 35(2), 153-171.

Judge, T. A., Thoresen, C. J., Bono, J. E., \& Patton, G. K. (2001). The job satisfaction-job performance relationship: A qualitative and quantitative review. Psychological Bulletin, 127(3), 376-407.

Judge, T. A., \& Watanabe, S. (1993). Another look at the job satisfaction-life satisfaction relationship. Journal of Applied Psychology, 78(6), 939-948.

Keser, A. (2006). Çağrı merkezi çalışanlarında iş yükü düzeyi ile iş doyumu ilişkisinin araştırılması. Kocaeli Üniversitesi Sosyal Bilimler Dergisi, 11(1), 100-119.

Kırcı-Çevik, N., \& Korkmaz, O. (2014). Türkiye'de yaşam doyumu ve iş doyumu arasındaki ilişkinin iki değişkenli sıralı probit model analizi. Niğde Üniversitesi İktisadi ve İdari Bilimler Fakültesi Dergisi, 7(1), 126-145.

Koç, H., Yazıcıŏlu, İ., \& Hatipoğlu, H. (2009). Öğretmenlerin iş doyum algıları ile performansları arasındaki ilişkinin belirlenmesine yönelik bir araştırma. Ondokuz Mayıs Üniversitesi Ĕ̆itim Fakültesi Dergisi, 28, 13-22.

Köseoğlu, S. (2017). Milli Ĕ̆gitim Bakanlığg'na bağhı okullarda çalışan idarecilerin iş tatminine yönelik bir uygulama. Tezsiz yüksek lisans projesi, Trakya Üniversitesi, Sosyal Bilimler Enstitüsü, Edirne.

Kubilay, S. (2013). Eğitim kurumlarında görev yapan yöneticilerin iş doyumu ve yaşam doyumu düzeylerinin incelenmesi: Niğde ili örneği. Yüksek lisans tezi, Erciyes Üniversitesi, Eğitim Bilimleri Enstitüsü, Kayseri.

Maforah, T. P. (2015). Secondary schools principals and their job satisfaction: A test of process theories. Journal of International Education and Leadership, 5(2), 1-10.

Milli Eğitim Bakanlığı [MEB] (2013). Milli Ĕ̆itim Bakanlı̆̆ı ortaöğretim kurumları yönetmeliği, Tarih: 07.09.2013, Sayı: 28758

Özkalp, E., \& Kırel, Ç. (2018). Örgütsel davranış. Bursa: Ekin.

Postma, K. L. (2019). The influence of self-efficacy on job satisfaction in New Jersey public school principals. Doctoral dissertation, Seton Hall University. 
Recepoğlu, E. (2008). Okul müdürlerinin mizah yeteneğinin öğretmenlerin iş doyumlarına etkisi. Eğitim ve Bilim, 33(150), 74-86.

Soylu, S. (2004). Telekomünikasyon sektöründe örgütsel kültürün oluşmasında insan kaynakları uygulamalarının etkisi ve iş doyumu ile ilişkisi. Doktora tezi, Ege Üniversitesi, Sosyal Bilimler Enstitüsü, İzmir.

Spector, P. E. (1997). Job satisfaction: Application, assessment, causes and consequences. Thousand Oaks. CA: Sage

Şahin, S., Çek, F., \& Zeytin, N. (2011). Eğitim müfettişlerinin mesleki memnuniyet ve memnuniyetsizlikleri. Kuram ve Uygulamada Eğitim Yönetimi, 17(2), 221-246.

Şişman, M. (2016). Türk eğitim sistemi ve okul yönetimi. Ankara: Pegem Akademi.

Turan, M., \& Parsak, G. (2011). Yabancılaşma ve iş tatmini ilişkisi: Bir devlet üniversitesi idari personeli üzerinde araştırma. Çukurova Üniversitesi Sosyal Bilimler Enstitüsü Dergisi, 20(2), 120.

Wright, T. A., \& Cropanzano, R. (2000). Psychological well-being and job satisfaction as predictors of job performance. Journal of Occupational Health Psychology, 5(1), 84-94.

Yıldırım, İ., Akan, D., \& Yalçın, S. (2017). Sınıf öğretmenlerinin iş doyumu ve okul etkililiği algıları arasındaki ilişki. Erzincan Üniversitesi Eğitim Fakültesi Dergisi, 19(1), 69-81.

Yılmaz, E., \& Izgar, H. (2009). İlköğretimde çalışan öğretmenlerin iş doyumlarının okullardaki örgütsel yaratıcılık açısından incelenmesi. İlköğretim Online, 8(3), 943-951.

Yıldırım, A., \& Şimşek, H. (2011). Sosyal bilimlerde nitel araştırma yöntemleri. Ankara: Seçkin.

Yılmaz, K. (2012). İlköğretim okulu öğretmenlerinin iş doyumu düzeyleri ile örgütsel vatandaşlık davranışları arasındaki ilişki. Anadolu Üniversitesi Ĕ̆itim Bilimleri Enstitüsü Dergisi, 2(2), 1-14. 